\title{
A MODEL SELECTION FOR PRICE FORCASTING OF CRUDE PALM OIL AND FRESH FRUIT BUNCH PRICE FORECASTING
}
K. Sukiyono ${ }^{1}$
N. N. Arianti $^{1}$
B. Sumantri ${ }^{1}$
M. Mustopa Romdhon ${ }^{1}$
M. Suryanty ${ }^{1}$
T. Adiprasetyo ${ }^{2}$

1) Department of Agricultural Socio-Economics, Faculty of Agriculture, University of Bengkulu

2) Department of Soil Science, Faculty of Agriculture, University of Bengkulu

\section{ABSTRACT}

Correspondent Author: ksukiyono@unib.ac.id

This study was aimed to determining a fitted forecasting method for the forecasting of crude palm oil prices at international and domestic market as well as fresh fruit bunch prices at collecting merchant and farmer level in Bengkulu Province market by considering three models, namely, double exponential smoothing, autoregressive integrated moving average, and classical decomposition. The data used were monthly data of crude palm oil prices at domestic and world markets from January 2012 - October 2016 and January 2012 - April 2017, while the fresh fruit bunch data at collecting merchant and farmers in Bengkulu Province were also monthly data from 2007 - 2014. The result showedthat the most accurate method was ARIMA for all prices at all market levels. This decision was based on all criteria used to determine the best model including MAPE, MAD, and MSD.

Keywords: forecasting, exponential smoothing, ARIMA, decomposition method,CPO, FFB

سوكاينو واَخرون

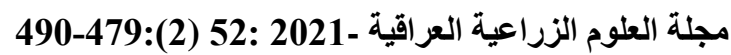
اختيار نموذج التأثير لاسعار زيت النخيل الخام وكتثة الفاكهة الطازجة في التتبؤ السعري
M. Mustopa Romdhon ${ }^{1}$
B. Sumantri ${ }^{1}$
N. N. Arianti
K. Sukiyono ${ }^{1}$
M. Suryanty ${ }^{1}$ T. Adiprasetyo ${ }^{2}$

$$
\begin{aligned}
& \text { 1) قسم الاقتصاد الاجتماعي الزراعي ، كلية الزراعة ، جامعة بنجكولو }
\end{aligned}
$$

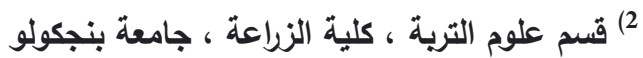

المستخلص

هدفت هذه الدراسة إلى تحديد طريقة تتبؤ مناسبة بأسعار زيت النخيل الخام في الاسواق العالمية والمحلية وكذلك أسعار باقة

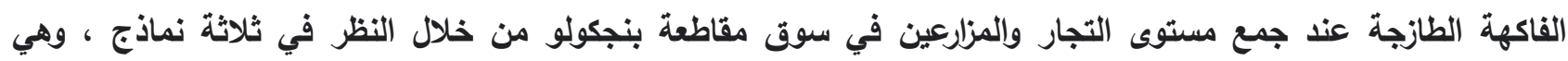
التجانس الأسي المزدوج ، ومتوسط متحرك متكامل ذاتي الانحار ، وتحلل كلاسيكي. كانت البيانات المستخدمة عبارة عن في في بيانات شهرية لأسعار زيت النخيل الخام في الأسواق المحلية والعالمية من يناير 2012 - أكتوير 2016 ويناير 2012 - 2012 أبريل 2017 ، بينما كاتت بيانات مجموعة الفاكهة الطازجة في جمع التجار والمزارعين في مقاطعة بنجكولو بيانات شهرية لانية أيضًا من 2007 - 2014. أظهرت النتيجة أن الطريقة الأكثر دقة هي ARIMA لجميع الأسعار وعلى جميع مستويات

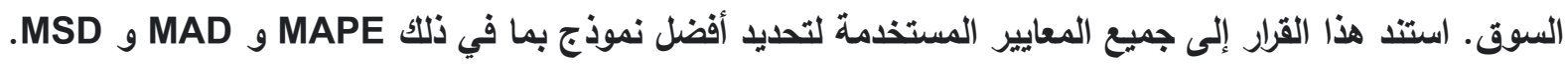
الكلمات المفتاحية : التنبؤ ، التسوية الأسبة ، ARIMA ، طريقة التحلل ، FFB CPO 


\section{INTRODUCTION}

The palm oil industry plays a significant role in Indonesian export. The total exports of palm oil commodities throughout 2016 reached IDR 240 trillion or nearly $14 \%$ of non-oil and gas export with the production of 25.67 million tons. Indonesia is one of the world's largest suppliers of crude palm oil (CPO) at 34 metric tonslast season, or 54\% of the global supply (10). This industry also involved 1.5 million households (24). Therefore, due to high dependence on the international market, the Indonesian palm oil industry hasbeen barely impacted by a decrease in CPO demand and price. With a continuous decline in the price and demand of CPOin the world market in 2015, for example, selling prices of fresh fruit bunch (FFB) of oil palm in different districts in Indonesia might have encountered wildprice distortions within the last five years (14). The adverse effects hit not only CPO producers andexporters, but also farmers. A study by Sukiyono, Cahyadinata, Purwoko, Widiono, Sumartono, Arianti, \& Mulyasari (28) concluded that both plasma and non-plasma oil palm households were most impacted by the frequently decreasing FFB price, in whichplasma oil palm growers were more sensitive than non-plasma. The study also discovered that oil palm farmers with limited palm oil area were more vulnerable compared to larger oil palm growers. This discussion suggestedthat due to the significant effect of price fluctuations on producers and consumers, they should recognize and understand the pattern of price volatility to avoid the risk of loss. Hence, the existence of CPO price forecasting information will facilitate producers and consumers in handling loss risk. Forecasting the price of valuable commodities, such as oil palm, is essential for all stakeholders involvedin palm oil industries. Unquestionably, price forecast is also useful for policymakers to design and formulate macroeconomic policies including supporting the agricultural sector as noted by Bowman \& Husain (3) and Xin \& Can (32). In addition, Jha \& Sinha (15) stated that agricultural price forecasts help farmers strategize their production and marketing on the predicted prices. For palm oil farmers, appropriate forecasting changes in FFB prices would guide them in the production and marketing of their products as well as prepare themselves economically in facing a decline in FFB prices. Therefore, the research aimed at forecasting prices of $\mathrm{CPO}$ and FFB is of great significance. Price forecasting can be defined as an attempt to predict the future of price based on previous data references. Various forecasting techniques have been applied to forecast price depending on the availability of data, time horizon, and objectives. Broadly, two basic approaches to forecasting can be classified, namely, qualitative and quantitative $(5,6$, 12). Qualitative approaches are forecasting techniques based on the judgment of consumers or experts. Thus, these approaches are subjective and appropriate in the absence of previous data. Quantitative forecasting method, on the other hand, can be used when two conditions are met (a) the availability of previous numerical data; and (b) assumption that the existence of some past patterns in the futurewill prevail (13). Compared to qualitative approaches, also known as judgemental methods, quantitative techniques based on statistical techniques are better in terms of their accuracy. Numerous quantitative forecasting methods are available, from a simple model (trend forecasting model) to a more complex model (suh as Autoregressive Integrated Moving Average $=$ ARIMA). Each method has its properties, accuracies, and costs. These properties must be taken into account when choosing a specific method. Quantitative methods are grounded in statistical and mathematical concepts. They are categorized into (a) Time series forecasting, i.e., the forecasted variables behave according to a particular pattern in thepast and that trend will continue in the future; and (b) Causal forecasting, i.e., cause and effect relationship between the predicted variable and another or a series of variables. Among forecasting models, time series forecasting method is popular among forecasters because it is easy to understand and explain. The simplest forecasting models are a naive model, assumingthat recent period is the best forecaster of the future.This technique is understandable, takes nocalculations, and cheap. Forecasting techniques are then 
developed and designed to be more complex along with an increasing need for accuracy in forecasting. Among those techniques are an exponential smoothing model (30), ARIMA models and composite models $(17,25,27,29$, 31, 32). Three-time series forecasting methods were used in this paper, namely, double exponential smoothing, ARIMA, and classical decomposition. This article was intended to determine the best forecasting method for the world and domestic CPO prices and FFB price in Bengkulu Province.

\section{MATERIALS AND METHODS \\ Data and source of data}

This study usedmonthly CPO and FFB price data. CPO price data consisted of domestic market (Medan) and world market (Rotterdam) involving 118 observations from January 2007 - October 2016. Meanwhile, FFB price data were collected from provincial plantation office in Bengkulu consisting of FFB prices at farmers and collecting merchants. The FFB data were only available from January 2007 to December 2014 or 96 observationsbecause since then, the plantation office stopped collecting these data

\section{Forecasting Model}

\section{Double Exponential Smoothing}

Double Exponential Smoothing is applied when data show a trend (19). Kalekar (16) noted that exponential smoothing with a trend

$$
Y_{t}=\phi_{1} Y_{t-1}+\phi_{2} Y_{t-2}+\ldots+\phi_{p} Y_{t-p}+\varepsilon_{t}+\varphi_{1} \varepsilon_{t-1}+\ldots+\varphi_{q} \varepsilon_{t-q}
$$

where $\mathrm{t}=1,2,3 \ldots \mathrm{T} \varepsilon_{t}$ is an uncorrelated process with mean zero, $\phi_{i}$ and $\varphi_{i}$ are coefficients (to be determined by fitting the model)

The Box-Jenkins methodology consists of identifying, selecting, and assessingconditional mean models and univariate time series data (21). The first step is to check the data stationarity since theestimation procedure is only for stationarydata. Data are stationary if the mean and the autocorrelationstructures of the variables are constant over a time series data period. If the stochastic trendexists, it is removed by differencing and variance stabilization is conducted by applying the logarithmic transformation.

\section{Decomposition Forecasting Model}

Decompositionmethods involve decomposing time series data into 4 components, i.e.,trend, workssubstantially like basic smoothing, but the level andpattern components must be revised each period. The data at the end of each period were smoothed,estimated as the level. At the end of each period, the average growth that had been smoothed indicated the trend.An approach used to handle a lineartrend is called the Holt's two-parameter method (25).

Three equationsused are as follows:

$$
\begin{aligned}
& A_{t}=\alpha Y_{t}+(1-\alpha)\left(A_{t-1}+T_{t-1}\right) \\
& T_{t}=\beta\left(A_{t}-A_{t-1}\right)+(1-\beta) T_{t-1} \\
& Y_{t+x}=A_{t}+x T_{t}
\end{aligned}
$$

where $A_{t}=$ smoothed value; $\alpha=$ smoothing constant $(0<a<1) ; \beta=$ smoothing constant for trend estimate $(0<\beta<1) ; \quad T_{t}=$ trend estimate, $x=$ periods to be forecasted into future, and $Y_{t+x}=$ forecast for $x$ periods into the future.

\section{ARIMA Model}

ARIMA processes, a class of stochastic processes, werefirst usedto analyze time series by Box \& Jenkins (4). ARIMA model,also known as Box-Jenkins model, is established by using past values and random disturbed variable. The model is designated as ARIMA $(\mathrm{p}, \mathrm{d}, \mathrm{q})$ where $\mathrm{p}, \mathrm{d}$, and $\mathrm{p}$ are autoregressive, integrated, and moving average which areparts of the model. The general equation of an ARIMA (p,d,q) model is given by:

seasonal, cyclical anderrorcomponent (23). The model is

$$
Y_{t}=f(T, C, S, e)
$$

This model assumes that $Y_{t}$ the actual time series value atperiod $t$, is a function of four components: seasonal (S), cyclical $(C)$, trend $(\mathrm{T})$ anderror $(e)$. These components are combined to generate theobserved values of the time series dependingon their relationship whetherit is an additive or a multiplicative decomposition model (22).

An additive decomposition model has the following form:

$$
Y_{t}=T_{t}+C_{t}+S_{t}+e_{t}
$$

In this additive model, the values of the four components are simply added together toobtain the actual time series value $Y_{t}$. The error component accounts for the variabilityin 
the time series that other elements in the modelare unable to explain.

A multiplicative decomposition model can be written as:

$Y_{t}=T_{t} \times C_{t} \times S_{t} \times e_{t}$

In this model, trend, cyclic, seasonal and irregular components are multiplied to generate thevalue of time series.

\section{Model Selection}

In many forecasting situations, Makridakis \& Wheelwright (20) stated that measuring forecasting error for a given set of data and a given forecasting technique has become critical concerns. Error testing, i.e., the difference between the value of forecasting and the actual value, is seen as a way of looking at the precision of a forecasting method. In this study, three criteria for measuring accuracy were chosen to assess the six forecasting models, namely Mean Absolute Deviation(MAD), Mean Squared Deviation (MSD), and Mean Absolute Percent Error (MAPE). The first accuracy measurement used in this paper was MAD. MAD is the absolute average value of error regardless of whether the error is an overestimate or underestimate (18). The second measurement was MSD. MSD is similar to Mean Squared Error (MSE), a commonly-used measure of the accuracy of time series models (8). This method avoids positive and negative deviations from each other by squaring the error. The average squared difference between the predicted andthe actual values of $\mathrm{y}$ is MSD. MSD is used to assess how close a regression model matches the real data; a lower MSD indicates acloser fit. Finally, MAPE is the mean of the sum of all of the percentage errors for a given data set taken regardless of sign in order to avoid problems of positive and negative values canceling out one another (20). MAPE is calculated by subtracting the actual value from theforecast value and then dividing by the real value. The absolute value of the division is multipliedby 100 and divided by the number of observations. Similar to MAD and MSE, the smaller the MAPE, the better the forecasting model.

\section{RESULTS AND DISCUSSION}

Data Description:Domestic and World Price of CPO: The empirical analysis was conducted using monthly data on domestic and world prices from January 2007 until October 2016. Figure 1 plotsthe Domestic and World prices in the graph.

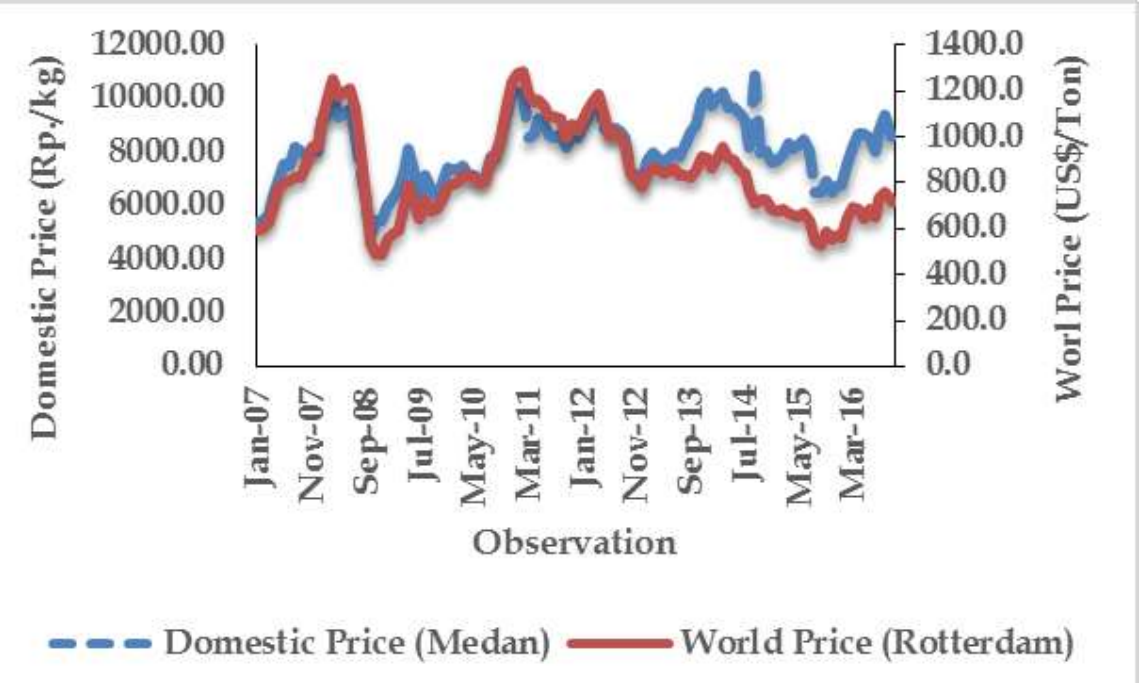

Figure 1. CPO price series at Domestic (Medan) and World Market (Rotterdam)

Looking at Figure 1, it seems that both world price and domestic price hadsimilar data pattern. The domestic and world CPO price data were not stationary, and the price fluctuations were not of fixed period meaning that they are cyclical, not seasonal. The cyclic component was seen with the increasing and decreasing fluctuations in the CPO price data in the non-fixed period. Cyclical data components are difficult to separate from trends and are often considered a part of trends (11), even though from Figure 1 it is difficult to recognize the presence of trend. The world and domestice prices of CPO tendedto be non stationary because of many factors, namely exchange rate, the price of soybean and coconut oil as alternative products of CPO that 
tend to fluctuate, demand and supply of CPO in areas where the price tends to be low.

\section{Provincial FFB Price}

The data at the provincial level were also monthly price data of FFB both atfarmers and collecting merchants level from January 2007 to December 2014 or 96 observations. Since January 2015, the provincial plantation office no longer recorded these data. The provincial data of FFB prices were likely to follow the data pattern of the domestic and world prices of CPO. Cyclical pattern was dominated by the
FFB prices at the provincial level. This finding is not surprising because the FFB pricing at the provincial level was also based on the world prices of CPO. Since 1998, the FFB pricing policy is determined by a Team established by the local government and referring to the Decree of the Minister of Forestry and Estate Crops 627/1998. However, the Decree was subsequently replaced by Regulation of the Minister of Agriculture (Permentan) No. 395 of 2005, but the contents did not change significantly.

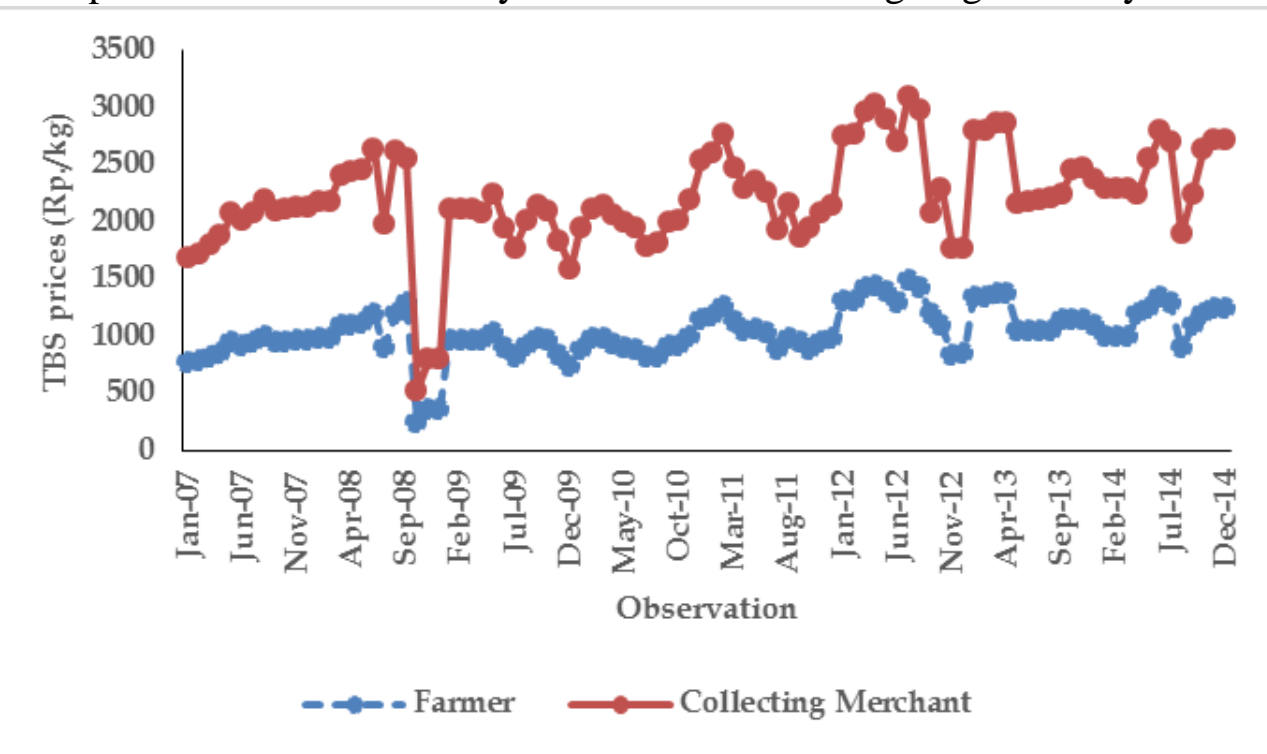

Figure 2. FFB price series at Collecting Merchants and Farmers in Bengkulu Province Forecasting Model Estimation and Model Selection

Double Exponential Smoothing: This double exponential smoothing method uses two smoothing coefficients, namely, ${ }_{\alpha}$ (smoothing constant) and $\beta$ (smoothing trend). These smoothing coefficients are determined by trial and error to produce the smallest error value

(26). An indicator used to select the fitted $\alpha$ and $\beta$ value is Root Mean Square Error (RMSE)in which the best value of ${ }_{\alpha}$ and $\beta$ is indicated by the smallest value of RMSE. The result of the forecasting models of CPO and FFB prices is presented in Table 1.

Table 1. Forecasting results using Double Exponential Smoothing

\begin{tabular}{|c|c|c|c|c|c|c|}
\hline \multirow{2}{*}{ No } & \multirow{2}{*}{ Prices } & \multirow{2}{*}{$\alpha$} & \multirow{2}{*}{$\beta$} & \multicolumn{3}{|c|}{ Accuracy Measure } \\
\hline & & & & MAPE & MAD & MSD \\
\hline \multirow[t]{3}{*}{1} & CPO Prices & & & & & \\
\hline & World Market & 1.06431 & 0.02073 & 5.26 & 42.07 & $3,185.0$ \\
\hline & Domestic Market & 1.06805 & 0.01904 & 6.00 & 488.00 & $4802,218.0$ \\
\hline \multirow[t]{3}{*}{2} & FFB prices at & & & & & \\
\hline & Collecting Merchant & 1.07128 & 0.02630 & 13.80 & 125.00 & $42,136.1$ \\
\hline & Farmers & 1.13346 & 0.01690 & 13.90 & 101.00 & $32,303.5$ \\
\hline
\end{tabular}

For the CPO prices at the world market, the best value for $\alpha$ and $\beta$ were 1.06431 and 0.02073 respectively while at the domestic market, the best value for $\alpha$ and $\beta$ were 1.06805 and 0.01904 . Looking at $\alpha$ and $\beta$ values, both markets were likely to have similar values. These indicate that both markets hada similar data pattern (also see Figure 1). For the FFB prices, the best value of $\alpha$ and $\beta$ were 1.071228 and 0.02630 at collecting merchant and 1.13346 and 0.01690 at farmer level. 


\section{ARIMA}

Stationary test: It should be noted that most time series data are nonstationary yetAR and MA aspects of ARIMA model require stationary periodical series. Stationarity means that data must roughly be horizontal along the time axis. In other words, the fluctuation of data is a constant average value, independent of the time and variance of the variation remains constant at all times. Non-stationary time series data must be converted into stationary data by differencing, calculatingthe

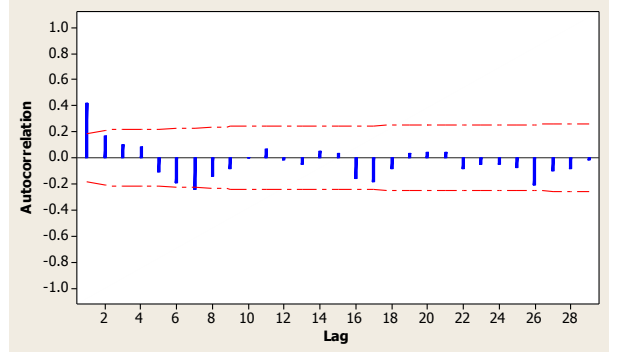

CPO prices at World Market*)

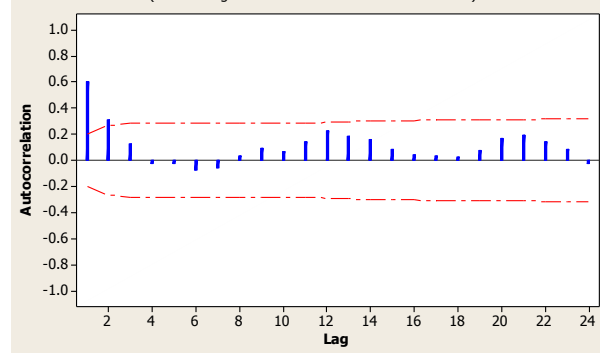

FFB Prices at Collecting Merchant

*) after differencing

Figure 3. Autocorrelation Function for CPO and FFB Prices

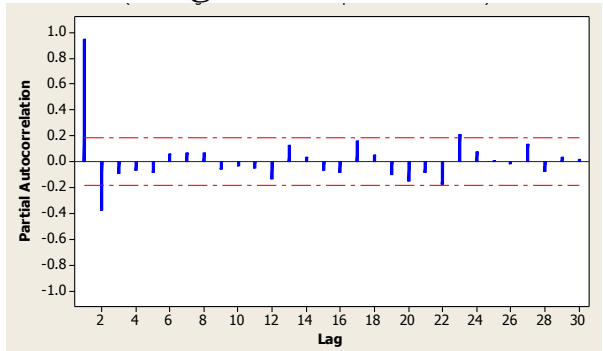

CPO prices at World Market

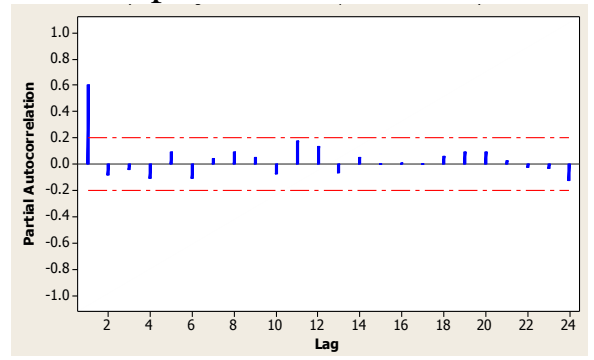

FFB Prices at Collecting Merchant change or the difference in the value of observation. The value of the difference obtained is then rechecked to find out whether it is stationary or not. If nonstationary, then another differencing is performed. If the variance is nonstationary, then a logarithmic transformation is performed. Thus, the first step is to determine the data stationarity as shown by autocorrelation and partial autocorrelation calculations as illustrated in Figure 3 and 4.

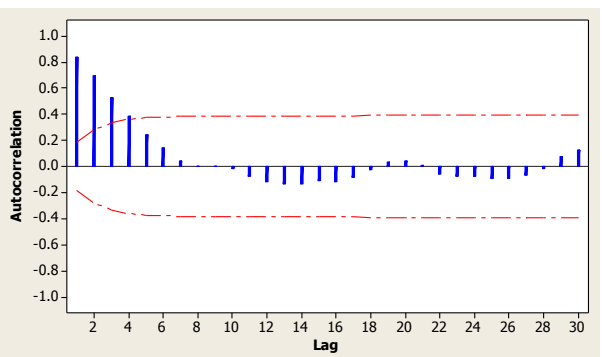

CPO prices at Domestic Market

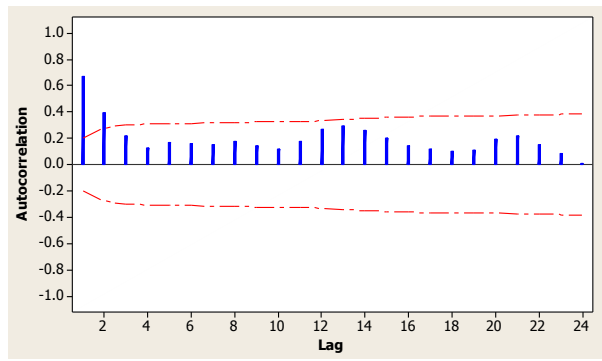

FFB Prices at Farmer Level

Figure 4. Partial Autocorrelation Function for CPO and FFB Prices

The graphs of autocorrelation and partial autocorrelation function as in Figure 3 and 4 showed that the formed autocorrelation

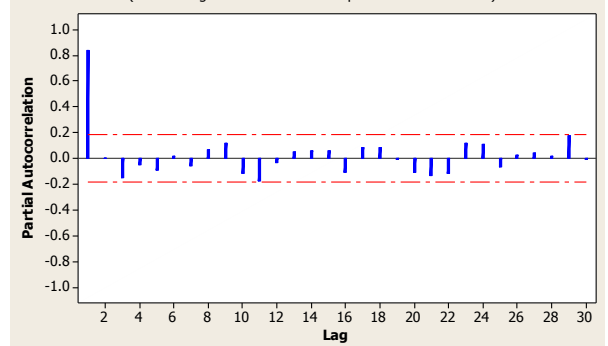

CPO prices at Domestic Market

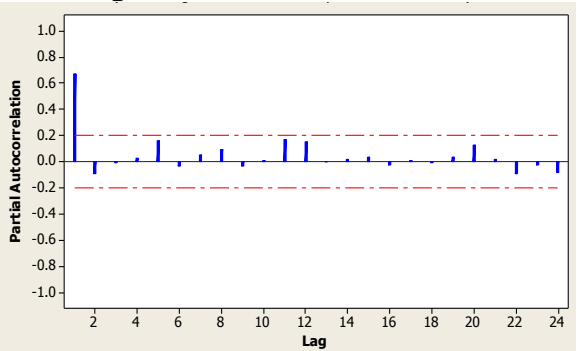

FFB Prices at Farmer Level

function was rapidly falling into a sinusoidal pattern while the formed partial autocorrelation function exhibitedinsignificant. 
Furthermore, the model checking done with Augmented Dickey-Fuller (ADF) unit root test on $\mathrm{CPO}$ and FFB prices confirmedthat the series was stationary, except for the CPO prices at the world market. After the firstdifference, the CPO prices at global market became stationary. Table 2 presents stationary test for the data used in this paper.

Table 2. Unit Root Test for Stationarity using Augmented Dickey-Fuller

\begin{tabular}{|clccl|}
\hline No & \multicolumn{1}{c}{ Data } & t - statistic & Prob & \multicolumn{1}{c|}{ Conclusion } \\
\hline 1 & World Price of CPO & -2.8498 & 0.0553 & Non-stationary*) \\
2 & Domestic Prices of CPO & -3.1241 & 0.0281 & Stationary \\
3 & FFB at Collecting Merchant & -4.7282 & 0.0002 & Stationary \\
4 & FFB at Farmers Level & -4.2822 & 0.0008 & Stationary \\
\hline
\end{tabular}

Estimation of World and Domestic CPO all the parameters were significant with Prices Model : Due to the non-stationary of the CPO prices at the world market, these data hadto be converted into stationary data at the first differencing. Then, the ARIMA model for the world CPO prices was estimated. After comparing all the fit statistics, it is found that the best model was ARIMA $(1,1,2)$ in which respective significant levels as presented in Table 5. Similar steps were also conducted for the domestic prices of CPO. It is found that the best ARIMA model for domestic prices was ARIMA $(1,0,4)$. The parameters of ARIMA $(1,0,4)$ with their respective significance levelsaregivenin Table 3.

Table 3. Estimated Model Parameters of World and Domestic PricesOf CPO

\begin{tabular}{|c|c|c|c|c|c|}
\hline No & Data & Coefficient & SE - Coefficient & t-statistic & probability \\
\hline \multirow[t]{4}{*}{1} & World Price of CPO & & & & \\
\hline & $\mathbf{A R}(\mathbf{1})$ & 0.9932 & 0.0535 & 18.55 & 0.000 \\
\hline & MA (1) & 0.6653 & 0.0086 & 76.91 & 0.000 \\
\hline & MA (2) & 0.3269 & 0.1024 & 3.19 & 0.002 \\
\hline \multirow[t]{6}{*}{2} & Domestic Prices of CPO & & & & \\
\hline & $\mathbf{A R}(\mathbf{1})$ & 1.0000 & 0.0002 & 5023.03 & 0.000 \\
\hline & MA (1) & 0.2077 & 0.0866 & 2.40 & 0.018 \\
\hline & MA (2) & 0.1927 & 0.0830 & 2.32 & 0.039 \\
\hline & MA (3) & 0.3091 & 0.0870 & 3.55 & 0.001 \\
\hline & MA (4) & 0.3960 & 0.0880 & 4.50 & 0.000 \\
\hline
\end{tabular}

\section{Estimation of FFB Prices Model}

The data of fresh fruit bunch prices, both at collecting merchant and farmer level were already stationary, so they did not need a differencing. From the estimation, it is found that the best model for the FFB prices at collecting merchant and farmer level was the same, i.e., ARIMA $(1,0,2)$.

Table 4. Estimated Model Parameters of FFB Prices at Collecting Merchant and Farmer Level

\begin{tabular}{|c|c|c|c|c|c|}
\hline No & Data & Coefficient & SE - Coefficient & t-statistic & probability \\
\hline \multirow[t]{4}{*}{1} & At Collecting Merchant level & & & & \\
\hline & AR (1) & 1.0002 & 0.0018 & 550.43 & 0.000 \\
\hline & MA (1) & 0.3951 & 0.0912 & 4.33 & 0.000 \\
\hline & MA (2) & 0.5061 & 0.0910 & 5.56 & 0.000 \\
\hline \multirow[t]{4}{*}{2} & At Farmer level & & & & \\
\hline & AR (1) & 1.0003 & 0.0030 & 331.99 & 0.000 \\
\hline & MA (1) & 0.3663 & 0.0933 & 3.93 & 0.000 \\
\hline & MA (2) & 0.4677 & 0.0932 & 5.02 & 0.000 \\
\hline
\end{tabular}

Decomposition Model

World and Domestic Prices of CPO

Based on the classical decomposition methods, the world CPO price forecasting results are presented in Figure 5 (a) and (b). Looking at this figure, both additive and multiplicative methods are likely to produce the same pattern and results. Looking at the fitted trend equation, both approaches have similar trends, i.e., a downward trend with a similar degree of slope. These results indicate that both methods can be used to forecast with a similar degree of 
accuracy. This conclusion is supported by the identical values of MAPE and MAD (Table 5). MAPE value for both decomposition forecasting model was $19.70 \%$, and MAD value for both models was 156.6. These inconclusive results imply that forecasters can use either additive or multiplicative to predict the world CPO prices. However, if looking at MSD value, the additive hada smaller MSD value than multiplicative. The MSD value of World Prices of CPO

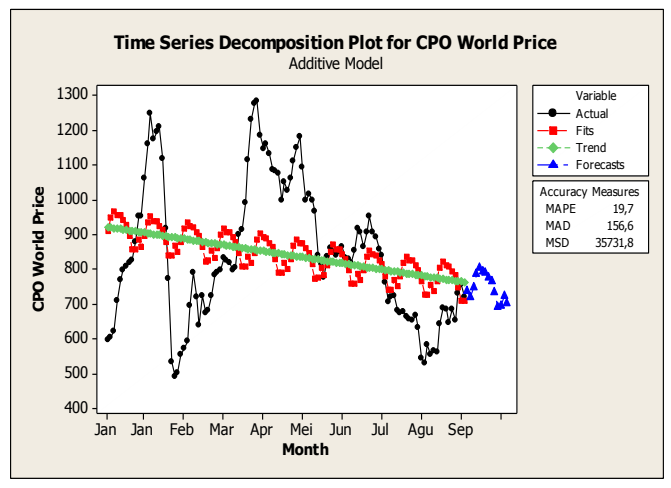

a) Additive Decomposition Model

\section{Domestic Prices of CPO}

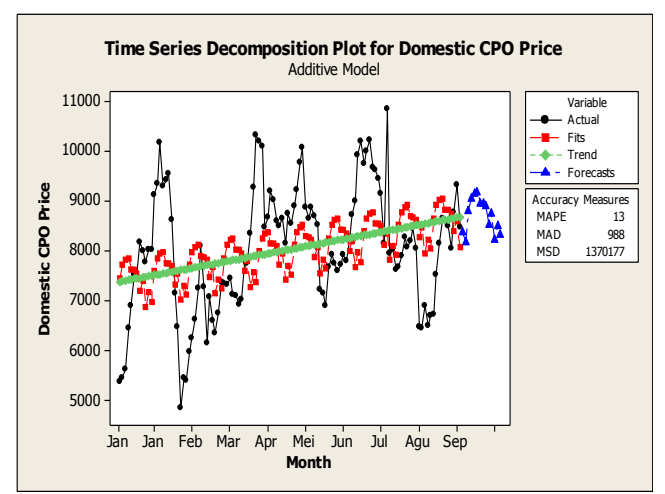

c) Additive Decomposition Model additive decomposition model was $35,731.8$ while the MSD value of multiplicative was 35,740.6. This result concludes that additive is more accurate than commutative in forecasting the world CPO prices. Based on this discussion, it is better to apply an additive decomposition model to forecast the world CPO prices for the period of January 2007 October 2016.

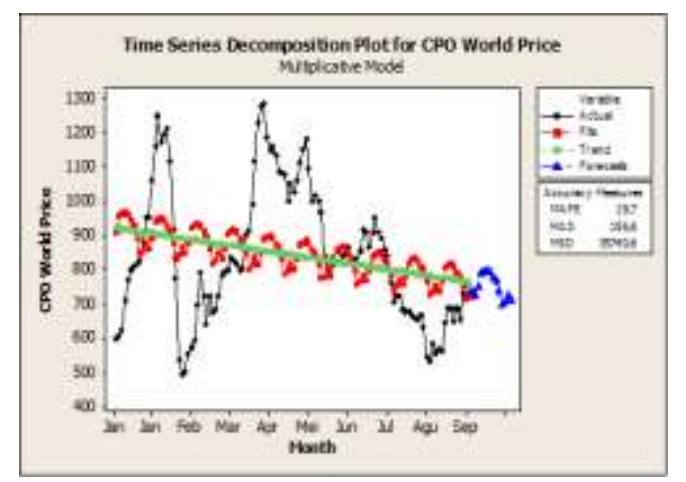

b) Multiplicative Decomposition Model

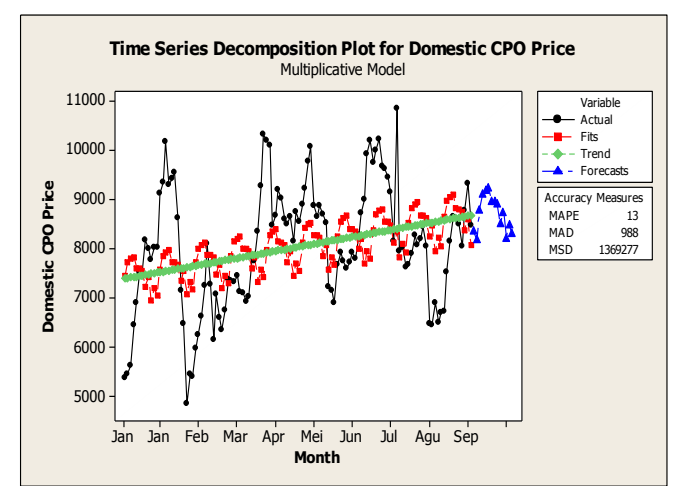

d) Multiplicative Decomposition Model

Figure 5. Forecasting Results of World and Domestic CPO Prices

The forecasting result of the domestic CPO prices is presented in Figure 5 (c) and (d). This figure also indicates that the forecasting results from additive and multiplicative have similar patterns and accuracies. The plots tend to have an upward trend and similar cyclical patterns. The upward trend of both additive and multiplicative has positive and quite similar slope described by its fitted trend equation. These results also imply that both forecasting models have a similar degree of forecasting accuracy. This means that,regardless of what decomposition models are used, they will produce identical results.
This conclusion is more convincing when viewed from the forecasting accuracy measurements, namely, MAPE and MAD (Table 5). MAPE and MAD value for both additive and multiplicative were similar, i.e., $13 \%$ and 938 respectively. Also, examining the MSD value, additive decomposition model was less accurate than multiplicative because its MSD value was higher than that of multiplicative, i.e., 1370177 for additive and 1369277 for multiplicative. For these reasons, it is better to apply a multiplicative decomposition model for estimating the future domestic prices of CPOin Indonesia. 
Table 5. Forecasting Accuracy for World and Domestic CPO Prices Using Decomposition Forecasting Model

\begin{tabular}{|c|c|c|c|c|}
\hline \multicolumn{2}{|c|}{ Decomposition types } & MAPE (\%) & MAD & MSD \\
\hline \multirow{3}{*}{ World Prices } & Additive & 19.70 & 156.6 & 35731.8 \\
\hline & Multiplicative & 19.70 & 156.6 & 35740.6 \\
\hline & Conclusion & Inconclusive & Inconclusive & Additive \\
\hline \multirow{2}{*}{ Domestic Prices } & Additive & 13 & 988 & 1370177 \\
\hline & Multiplicative & 13 & 988 & 1369277 \\
\hline
\end{tabular}

FFB Prices at Collecting Merchant and Farmer Level

The FFB prices at collecting merchant level behave similarly to domestic CPO prices. Thedecomposition plot of the FFB prices at collecting merchant level also showedcyclical and upward trend patterns as shown in Figure 6 (a) and (b). The estimation results using an additive and a multiplicative decomposition model showed that both models had similar fitted trend equation. By looking at the MAPE value, both additive and multiplicative had the same value, i.e., $16.50 \%$ (Table 6). Thus, using either additive or multiplicative to forecast FFB prices at collecting merchant level showed no difference. They produced

\section{Collecting Merchant Level}

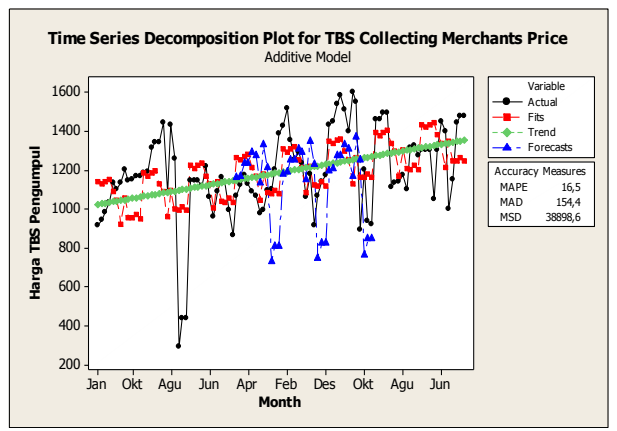

a) Additive Decomposition Model

Farmer Level

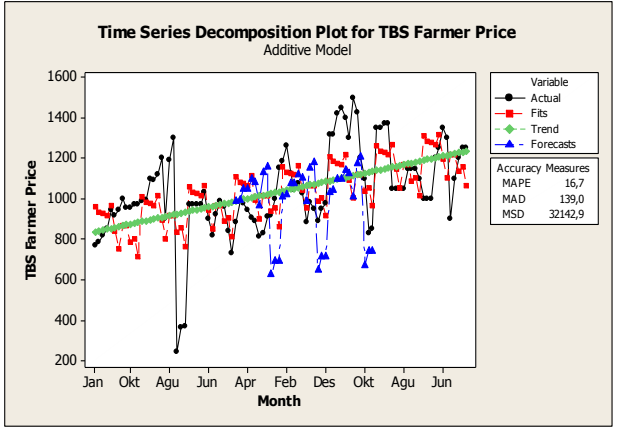

c) Additive Decomposition Model

Figure 6. Forecasting Results of $F$

A similar pattern was also found in the FFB forecasting at the farmer level, as presented in Figure 6 (c) and (d). Both additive and similar accuracies. However, considering the MAD and MSD values, both accuracy measurements producedthe opposite conclusions. Based on the MAD value, the multiplicative produced more accurate forecasting than additive. However, referring to the MSD value, the additive was more accurate because its MSD value was lower than that of multiplicative. Based on these findings, there is an inconclusive conclusion regarding the best decomposition forecasting method used to forecast the FFB prices at collecting merchant level. Forecasters can use either an additive or a multiplicative decomposition model.

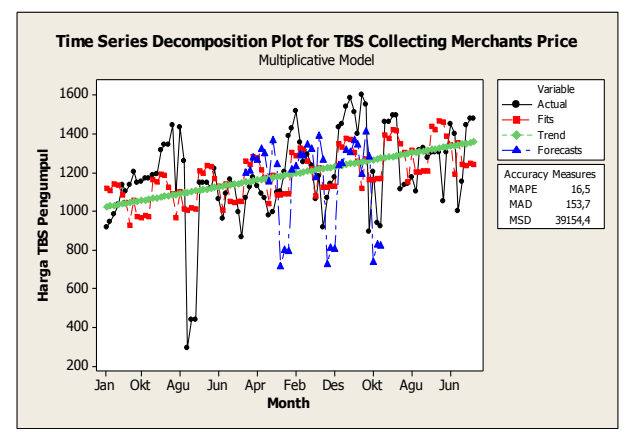

\section{b) Multiplicative Decomposition Model}

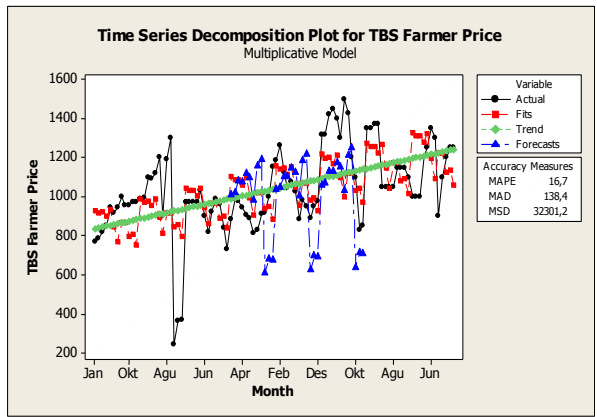

d) Multiplicative Decomposition Model

\section{Prices at Collecting Merchant Level}

multiplicative hadcyclical and upward trend pattern with an approximately similar degree of trend slope. From Table 6, if only based on 
the MAPE value, i.e., 16.7, it can be concluded that both models hadsimilarities regarding the level of accuracy. Forecasters will get a similar result from using either the additive or multiplicative to predict the FFB prices at farmers level. However, based on the MAD and MSD values, it is difficult to decide which decomposition model could produce a higher accuracy. Both accuracy measures produced a contradictory conclusion as in the FFB prices at collecting merchant level case. If the

Table 6. Forecasting Accuracy for FFB Prices at Collecting Merchant and Farmer Level Using Decomposition Forecasting Model Selecting an Accurate Model

\begin{tabular}{|llccc|}
\hline & Decomposition types & MAPE (\%) & MAD & MSD \\
\hline \multirow{3}{*}{ Collecting merchant } & Additive & 16.50 & 154.4 & 38898.6 \\
& Multiplicative & 16.50 & 153.7 & 39154.4 \\
& Conclusion & Inconclusive & Multplicative & Additive \\
& Additive & 16.7 & 139.0 & 32142.9 \\
Farmer level & Multiplicative & 16.7 & 138.4 & 32301.2 \\
& Conclusion & Inconclusive & Multiplicative & Additive \\
\hline
\end{tabular}

The forecasting methods discussed above were compared to each other using MAPE, MAD, MSD to determine the accurate forecasting model. Among the accuracy indicators of MAPE, MSE, and MAD, Gentry, Wiliamowski \& Weatherford (12) noted that MAPE provides the most accurate and fair comparison of forecasting methods. Following Gentry, Wiliamowski \& Weatherford (12), this paper decided mainly decision was based on MAD, the multiplicative decomposition model could give better forecasting accuracy than additive. Conversely, if the decision was based on MSD, the additive decomposition provided more accurate forecasting. Accordingly, based on the MAPE, MAD, and MSD measures, the conclusion was inconclusive, similar to thecase of the FFB prices at collecting merchant level. based on the MAPE value if two or more accuracy indicators having similar value were found. Table 7 shows the differences in theMAPE, MAD and MSD values for each forecasting method. As can be seen, all the accuracy indicator values of ARIMA were the lowest among those of the other methods, which means that the ARIMA model can be used as the best forecasting tool in time series analysis.

Table 7.MAPE, MAD, and MSD Values for EachForecasting Technique

\begin{tabular}{|c|c|c|c|c|}
\hline Forecasting Model & MAPE (\%) & MAD & MSD & Conclusion \\
\hline \multicolumn{5}{|l|}{ World CPO Prices } \\
\hline Double Exponential Smoothing & 5.260 & 42.070 & $3,185.010$ & \multirow{5}{*}{$\begin{array}{l}\text { ARIMA is the fit } \\
\text { model }\end{array}$} \\
\hline ARIMA & 5.109 & 41.149 & 55.188 & \\
\hline Decomposition & & & & \\
\hline Additive & 19.700 & 156.600 & $35,731.800$ & \\
\hline Multiplicative & 19.700 & 156.600 & $35,740.600$ & \\
\hline \multicolumn{5}{|l|}{ Domestic CPO Prices } \\
\hline Double Exponential Smoothing & 6.00 & 488.000 & $4,802,218.0$ & \multirow{5}{*}{$\begin{array}{l}\text { ARIMA is the fit } \\
\text { model }\end{array}$} \\
\hline ARIMA & 6.12 & 474.575 & 688.444 & \\
\hline Decomposition & & & & \\
\hline Additive & 13.00 & 988.000 & $\mathbf{1 , 3 7 0 , 1 7 7 . 0}$ & \\
\hline Multiplicative & 13.00 & 988.000 & $1,369,277.0$ & \\
\hline \multicolumn{5}{|l|}{ FFB Prices at Collecting Merchant } \\
\hline Double Exponential Smoothing & 13.800 & 125.000 & $42,136.100$ & \multirow{5}{*}{$\begin{array}{c}\text { ARIMA is the fit } \\
\text { model }\end{array}$} \\
\hline ARIMA & 13.644 & 185.159 & 122.940 & \\
\hline Decomposition & & & & \\
\hline Additive & 16.500 & 154.400 & $38,898.6000$ & \\
\hline Multiplicative & 16.500 & 153.700 & 39,154.400 & \\
\hline \multicolumn{5}{|c|}{ Domestic CPO Prices (FFB Prices atFarmer Level) } \\
\hline Double Exponential Smoothing & 13.900 & 101.000 & $32,303.500$ & \multirow{5}{*}{$\begin{array}{c}\text { ARIMA is the fit } \\
\text { model }\end{array}$} \\
\hline ARIMA & 13.422 & 101.352 & 164.796 & \\
\hline Decomposition & & & & \\
\hline Additive & 16.700 & 139.000 & $32,142.900$ & \\
\hline Multiplicative & 16.700 & 138.400 & $32,301.200$ & \\
\hline
\end{tabular}


To conclude, the primary goal of this study was to select the most appropriate forecasting technique for the future prices of CPO prices, both at domestic and world markets, and FFB prices at collecting merchant and farmer level in Bengkulu Province. Three types of forecasting methods were used in this study, namely, double exponential smoothing, ARIMA, and classical decomposition methods. The forecasting method was selected by least forecasting errors, that is, minimum values of MAPE, MAD, as well as MSD. Even though some decision is not always unanimous, it is found that the ARIMA model provides the most accurate prediction for $\mathrm{CPO}$ and FFB prices based on most of the accuracy measures.

\section{REFERENCES}

1. Adebiyi, A. A., A. O., Adewumi, and C. K. Ayo, 2014. Stock Price Prediction Using the ARIMA Model. Paper presented at 2014 UKSim-AMSS 16th International Conference on Computer Modelling and Simulation. DOI: 10.1109/UKSim.2014.67

2. Bowerman, B. L., R. T., O'Connell, and A. B. Koehler, 2004. Forecasting, time series, and regression: An applied approach. Belmont, CA7 Thomson Brooks/Cole

3. Bowman, C. and A. Husain, 2004. Forecasting Commodity Prices: Futures Versus Judgment (March 2004). IMF Working Paper No. 04/41. Available at SSRN: https://ssrn.com/abstract $=878864$

4. Box, G. E. P. and G. M.. Jenkins, 1976.Time Series AnalysisForecasting and Control, Third ed. Englewood Cliffs, NJ: Prentice-Hall

5. Calantone, R. J., A., Di Benedetto, and D. Bojanic, 1987. A comprehensivereview of the tourism forecasting literature. Journal of TravelResearch, 26(2), 2839.https://doi.org/10.1177/0047287587026002 07

6. Cleveland, R. B., W. S.,Cleveland, J. E. McRae, and I. Terpenning, 1990. STL: A Seasonal-Trend Decomposition Procedure Based on Loess (with Discussion). Journal of Official Statistics, 6, 3-73.

7. Directorate General of Estate Crops. 2016. Statistik Perkebunan Indonesia: Kelapa Sawit 2015 - 2017. Jakarta
8. Gauch, H. G., Jr., J. T. Hwang, and G. W. G.and Fick, 2003. Model Evaluation by Comparison of Model-Based Predictions and Measured Values. Agronomy Journal, 95 (November-December2003), 1442 - 1446. Retrieved from www2.geog.ucl.ac.uk/ mdisney/.../gauch_mod el_eval.pdf

9. Gentry, T. W., B. M. Wiliamowski, and L. R. Weatherford, 1995. A Comparison of Traditional Forecasting Technique and Neutral Network. Retrieved from http://www.eng.auburn.edu/ wilambm/pap/19 95/ANNIE'95_A_comparison_of_traditional_f orecasting.pdf

10. Hanke, J. E., and A. G. Reitsch, 1995. Business Forecasting ( $5^{\text {th }}$ ed.). Englewood Cliffs, NJ7 Prentice-Hall

11. Hanke, J.E., A.G., Reitsch, and D.W. Wichern, 2003. Business Forecasting Seventh Edition, Williams Publishers

12. Hyndman, R. J. 2009. Forecasting overview. November 8, 2009, available at https://robjhyndman.com/papers/forecastingov erview.pdf

13. Hyndman, R. J. and A. B. Koehler, 2006. Another look at measures of forecast accuracy. International Journal of Forecasting. 22, $679-$ 688. DOI:10.1016/j.ijforecast.2006.03.001

14. Infosawit (11 September 2015).Accessed from https://www.infosawit.com/.../harga-tbsjambi-naik--periode-11-17-september-2015

15. Jha, G. K. and K. Sinha, 2013. Agricultural Price Forecasting Using Neural Network Model: AnInnovative Information Delivery System. Agricultural Economics Research Review. 26 (2) July-December 2013: 229-239. Retrieved from https://ageconsearch.umn.edu/bitstream/16215 0/2/8-GK-Jha.pdf

16. Kalekar, P. S. 2004. Time series Forecasting using Holt-Winters Exponential Smoothing. Kanwal Rekhi School of Information Technology. Available at https://labs.omniti.com/people/jesus/papers/hol twinters.pdf

17. Khan, T. F., Sayem, S. M. and M. S. Jahan, 2010. Forecasting price of selected agricultural commodities In Bangladesh: An Empirical Study. ASA University Review, January-June 2010 4(1): 15 - 22. Retrieved from 
http://www.asaub.edu.bd/data/asaubreview/v4 n1s12.pdf

18. Krajewski, L. J., and L. P. Ritzman, 1993. Operations Management: Strategy and Analysis, $5^{\text {th }}$ Edition. Pearson

19. Lim, P. Y. and C. V. Nayar, 2012. Solar irradiance and load demand forecasting based on single exponentialsmoothing method.International Journal of Engineering and Technology. 4(4):451 - 455. DOI: 10.7763/IJET.2012.V4.408 Retrieved from www.ijetch.org/papers/408-P016.pdf

20. Makridakis, S., S. C. Wheelwright, and R. J. Hyndman. 1998. Forecasting Methods and Applications. New York, John Wiley and Sons 21. Pankratz, A. 1983.Forecasting with Univariate Box-Jenkinsmodels: concepts and cases. New York: John Wiley \& Sons

22. Peng, W. Y. and C. W. Chu, 2009. A comparison of univariate methods for forecasting container throughput volumes. Mathematical and Computer Modelling. 50 (2009), 1045 - 1057. https:// doi.org/ 10.1016/j.mcm.2009.05.027

23. Rajchakit, M. 2017. A New Method for Forecasting via FeedbackControl Theory. Proceedings of the International MultiConference of Engineers and Computer Scientists 2017 Vol I,IMECS 2017, March 15 - 17, 2017, Hong Kong. Retrieved from http://www.iaeng.org/publication/IMECS2017

24. Sensus Pertanian. 2013. Laporan HasilSensus Pertanian2013. BPS Jakarta

25. Sriboonchitta, S., H. T., Nguyen, A., Wiboonpongse, and J. Liu, 2013. Modeling volatility and dependency of agricultural price and production indices of Thailand: Static versus time-varying copulas. International Journal of Approximate Reasoning 54, 793 808.

http://dx.doi.org/10.1016/j.ijar.2013.01.004

26. Stevenson, W. J. 2009. Operations Management, 10th edition, Mc Graw Hill Inc, New York
27. Sukiyono, K. and Rosdiana. 2018. Pendugaan model peramalan harga beras pada Tingkat grosir. agrisep 17(1), 23 - 30. DOI: 10.31186/jagrisep. 17.1.23-30. Retrieved mfrom https:// ejournal.unib. ac.id/index.php/agrisep/article/view/4503 /pdf 28. Sukiyono, K.,I. Cahyadinata, A. Purwoko, S. Widiono,E. Sumartono, N.N.Arianti, and G. Mulyasari, 2017. Assessing smallholder household vulnerability to price volatility ofPalm fresh fruit bunch in Bengkulu Province. International Journal of Applied Business and Economic Research. 15(3), 1 15.http://www.serialsjournals.com/serialjourna lmanager/pdf/1490596894.pdf

29. Sukiyono, K., M. Z. S.P. Yuliarso, E. Utama, R. Yuliarti, R.Novanda, and B. S.Priyono. (2019). Possible method For monthly naturalRubber price forecasting. Journal of Advanced Research in Dynamical and Control Systems - Jardcs, 11, (Issue-07): 387 - 395. 2019. https:// www.jardcs.org /abstract. php?id=2555

30. Taylor, J. 2003. Short-term electricity demand forecasting using double seasonal exponential smoothing. The Journal of the Operational Research Society,54(8), 799-805. Retrieved from http://www.jstor.org/stable/4101650

31. Taylor, J. W. 2008. An evaluation of methods for very short-term load forecastingusing minute-by-minute British data. International Journal of Forecasting. 24, 645- 658 https:/ /doi.org/ 10.1016/j .ijforecast.2008.07.007

32. Xin, W. and W.Can, 2016. Empirical study on agricultural products price forecasting based on internet-based Timely price information. International Journal of Advanced Science and Technology. 87, 31-36. http://dx.doi.org/10.14257/ijast.2016.87.04. 